GLOBAL JOURNAL OF EDUCATIONAL RESEARCH VOL 11, NO. 2, 2012: 87-97

COPYRIGHTC BACHUDO SCIENCE CO. LTD PRINTED IN NIGERIA. ISSN 1596-6224 www.globaljournalseries.com; Info@globaljournalseries.com

\title{
AN ASSESSMENT OF INFORMATION BROKERAGE IN ACADEMIC LIBRARIES IN NIGERIA: UNIVERSITY OF CALABAR LIBRARY IN PERSPECTIVE.
}

\section{MARGARET EDEM AND PIUS TOM UMOREN}

(Received 24, April 2012; Revision Accepted 5, August 2012)

\begin{abstract}
This study is an assessment of information brokerage in the University of Calabar Library in the discharge of its functions to aid teaching, learning and research from 2005 to 2010. A descriptive survey design was adopted for the study and the total sampling procedure was used in selecting the seven divisional heads of the study. A checklist of University of Calabar Library Information Brokerage Delivery (IBD) Systems was prepared together with an interview schedule and used to elicit information from these librarians. The results showed that the University of Calabar Library has been engaging in information brokerage activities in the different units of the library through information merchandizing. It was discovered that patronage on brokerage activities and services were disproportionate among the units surveyed. The study showed that brokerage on publication services and system/technical services rated highest between the period covered by the study. The two brokerage delivery systems undertook 113 and 925 transactions and generated a substantial amount of income for the library. The study concludes that the University of Calabar Library is engaging enormously in information brokerage and thereby sustaining Entrepreneurship Education in library and Information Science in Nigeria. It is recommended that subject specialist librarianship be encouraged in academic libraries to facilitate the attainment of financial goals in the specialized services delivery in University Library as well as other tertiary institutions' libraries in Nigeria.
\end{abstract}

KEY WORDS: Information Brokerage; Information Products and Services; University of Calabar Library; Fee-Based Services; Entrepreneurship Education.

\section{INTRODUCTION}

Brokerage is an entrepreneurial business activity which people engage in to make a living. It is a business transaction in which practitioners depend largely on commission, computed and paid on agreed percentage by their principal. Brokers do not earn salaries. According to Garner (2009) brokerage is the business of a broker, who only earns commission for brokerage activities undertaken. It is important to note that brokers do not own the subject matter of transactions, but only use same to apply their trade earning commission. The Concise Oxford Dictionary of Current English describes a broker as "a middleman in bargains, agents, and a person licensed to sell or appraise distrained goods". It specifically centres around the business of intermediation for profit on commission.

In the same vein the Encyclopedia Americana (2003) states that brokerage activities generally are found in markets made up of many small, widely dispersed buyers and sellers where it is difficult for them to meet, thus requiring an intermediary

It is in this context that the need for a broker becomes imperative. The Encyclopedia Americana supra states that a broker may be a

Margaret Edem, University Library, University of Calabar, Calabar, Nigeria

Pius Tom Umoren, University Library, University of Calabar, Calabar, Nigeria 
single individual, a partnership or a corporate body. It goes on to add that the chief requisites for the calling as a broker are firm knowledge obtained from experience in the field of specialty and selling ability of the knowledge so acquired.

Stating the functions of a broker, the Colliers Encyclopedia (1995) posits that a broker being "one who acts as an agent for others in buying, selling and negotiating contracts and receiving commission in return" undertakes the following, among other functions:

i) Brokers for various kinds of informationrelated commodities and merchandize (as agents and distributors)

ii) Brokers for insurance activities (as insurance brokers)

iii) Brokers for financial transactions (as merchant banks and securities in the capital market)

iv) Provides services as an expert for and on behalf of the principal, promoter or proprietor, he is acting.

A cursory appraisal of items (i) and (iv) reveal that the library as an Information store house, acting through librarians is undertaking one form of brokerage activity or the other in the discharge of its traditional functions of information acquisition, processing, storage, retrieval and distribution in Nigeria's information highway. Thus, according to Uhegbu (2007:26) libraries are agents of information transfer in their bid to reach out to and serve the information seeker or user.

\section{BACKGROUND INFORAMTION \\ Information brokerage and Academic Libraries}

The library is a professional institution comprising experts in the field of information gathering, organisation, storage and dissemination. These are library functions where it can broker either on the demand or supply of what the International Federation of Library Association (IFLA) Council (1987) describes as information services that could attract charges. These information services according to Akintola (2006) include photocopying, internet use, quick enquiries, abstracting and indexing, etc. Thus librarians as professionals are information brokers who according to Johnstone (1995), are very well informed on the demand and supply in the aforementioned information products and services. Of course, it is right to say that
Librarians are well informed on issues bordering on current trends in information science and information service delivery system. In the light of the above context, libraries as specialized information institutions are daily engaging and promoting information brokerage thereby sustaining an aspect of entrepreneurship education in Nigeria. There is a clear existence of the two-way brokerage principle which are the capability of acting as a broker and also transacting with a broker. These accord with Unegbu (2007:29) who states that the provision of information without cost to beneficiaries for centuries past is fast changing with fees now being charged. He goes on to state that information brokering now reflects commercial tint having become a business undertaken by a person in this business known as "information broker".

\section{i) Acquisition of library information materials:}

This is a delivery function that librarians can broker through buying of the print and nonprint library materials of learning, teaching and research of the academic library clientele. It is also obvious that an academic library must have an acquisition or resource development division as is the case in the University of Calabar Library. Brokerage could also be undertaken in this aspect of library function if vendors and other materials' agents subscribe to assisting in information sharing for different libraries for pecuniary benefits.

\section{(ii) Processing of library information} materials:

This is a delivery function that librarians use to organize and make every acquired material ready for use by the clientele. Librarians can broker by using this delivery system to assist other libraries that do not process the necessary technical know-how in cataloguing and classification of their library materials. This service could extend to cover indexing and abstracting of author's works ready for publication. Brokers can also engage in connecting libraries with cataloguing and classification facilities to those without for commission. 
(iii)

$$
\text { Storage of library information }
$$
materials:

This service delivery function employs the most appropriate and ideal storage facilities to save and store every library information material for easy accessibility and retrieval as well as safe custody. The librarians here can broker in information retrieval and dissemination to researchers globally with the use of appropriate gadgets especially the Information Communication Technology (ICT) Systems. Of course, the application of the computers and other reprographic gadgets to retrieve and disseminate information to outsiders usually attracts pecuniary benefits to the sponsoring library.

\section{(iv) Retrieval and dissemination of library information materials}

This service delivery function involves the use and application of a multi-faceted service delivery systems. These include ICTs, printing and publishing devices, reprographic devices as well as binding devices.

In these delivery systems, librarians can broker in rendering information and other professional services to their clients through:

- Typesetting of manuscripts using the principal's computers

- Aiding clients source for and disseminate information through the library internet facilities.

- Printing client's manuscripts

- Publishing client's printed works. Issues bordering on charges for ISSN and ISBN, copyright retainership and commission on royalties will serve as grounds for brokerage and merchandising transactions.

- Aid clients locate materials to retrieve information of choice in the library either through manual card catalogue and/or the online public access catalogue (OPAC) which functions often times involve brokerages for the retrieval and dissemination of one information or the other. (v)

Professional Information Services Delivery function:

The library like any other professional institution engages in in-service and out-service training programmes. Such programmes are usually specialized in nature in a bid to accomplishing its professional mandates and also carry-out its community service responsibilities. Thus librarians can broker through organizing and mounting:

- Specialised training programmes to fill pertinent information gaps in the academia and other areas of human activity

- Specialized training workshops for professionals in the library information delivery services as well as for other information practitioners and

- Undertaking outreach information activities to sensitise potential library users in non-traditional library institutions and those that intend to make use of any of the library delivery systems to reach their goals. Of course, the library conference centre, the ICT, the printing and binding facilities are source areas where one form of the information brokerage and merchandizing can be undertaken.

\section{Information Brokerage in University of Calabar Library}

The methods of providing library and information services in academic libraries are changing because of the unfolding quest for information accessibility. This is very much so because library clients are now more interested in the collection contents of the materials in the library and the mode through which such contents can be accessed. This position is supported by Nkanu (2008) where he states that Nigerian University Libraries have now become the perceived place to access all the information needed by library clients. Therefore, it is not surprising that there is clear evidence in the changing roles of academic librarians in the areas of collection development, processing, storage and dissemination services. 
The University of Calabar Library, in the light of the foregoing, is a perfect replicate of an ideal academic library. This is so because it possesses all the identified features of a library and information centre with all the earlier listed information delivery systems. These delivery systems are constantly applied in information brokerage and merchandizing functions by the University of Calabar Library to satisfy the quest for accessibility of information of its clients. Therefore, this study will assess the availability of information brokerage transaction using the following service delivery systems in the University of Calabar Library:

* Resource acquisition;

* Distribution of information resources;

* Cataloguing and classification of information resources;

* Indexing and abstracting;

* ICT's service delivery via: browsing, downloading, scanning, reprographic services, e-mailing, printing and publishing; - charges on ISSN, ISBN, copyright retainership, commission on royalties;

srokerage on professional services viz:

- Specialized training programmes

- Specialized training workshops (specially for non-library and information practitioners using library facilities like the Library Conference Centre, Printing/Binding facilities etc)

- Outreach activities.

\section{Purpose of the study:}

The study seeks to examine:

- The availability of Information Brokerage in the University of Calabar Library;

- The effect of Unical Library's Information acquisition, storage and dissemination on information brokerage delivery systems

- The impact of Unical Library's Information brokerage (IB) on Entrepreneurship Education in Library and Information Science;

- Whether Unical Library's Information brokerage enhances resource sharing for advancement of teaching, learning and research.

\section{Literature Review}

The academic library is a Corpus with accumulation of interdisciplinary information materials which must be disseminated. It is in the light of the foregoing that Ani (2008) has posited that the prevailing information age is characterized by the free flow of information which is made possible with the recent adoption, application and utilization of modern information and communication technologies (ICTs) in information management, processing, storage, retrieval and dissemination in libraries. It is these identified service delivery areas, that academic libraries (and others who establish them) undertake brokerage services.

In a wider context brokerage activities require the knowledge of the economics of information. According to Akintola (2006) this will aid in determining which information services to be charged more comfortably and ones to be free-based. Still in the context of the economics of information, Ifidon and Nwalo (2003) posit that when planning for service delivery there must be price-fixing and fee-charging for services offered in public libraries as in the case of the Oyo State Library Board.

Thus since academic libraries also plan for service delivery for effective discharge of information and professional functions, brokerages in the form of fee-charge and pricefixing of necessity, form part of such planning.

In support of information brokerage, in the context of economics of information, the Infolibra (2005) in a Communiqué issued by the CRS Chapter of the Nigerian Library Association after its meetings agreed that "information brokerage should be marked driven, attracting financial returns from the end user".

In a study to determine the feeling of library users with regard to charging of fees for library services rendered, Ofre and Okwueze (2009) find out that respondents considered payment for some services such as internet services, literature search and current awareness services as desirable in the University of Calabar Library.

In the same vain, Edoka (1991) had long suggested that the following services in the library should be monitised. These are photocopying, interlibrary loan transaction, long enquiries, compilation of reading lists and 
literature searches, abstracting, document delivery, business/industrial information service and quick enquiries. These services are brokerage oriented and academic libraries are engaging in them and realizing pecuniary benefits.

In commercialization of the certain services offered in academic libraries, Ifidon (2005) in her study found users suggesting that external library users and researchers should be charged profit motive fees for services and that the use of ICT is unavoidable a fee-based library and information services.

In a narrow context, librarians in academic libraries act as brokers while discharging the functions of their libraries to their clients in information gathering, processing, storage and dissemination using the underlisted reader service and other delivery functions:-

\section{Availability of brokerage in resource acquisition:}

Nwamba (2002) states that University Libraries have now shifted their focus on operation from a traditional library institution to an information provider. He goes on to add that libraries utilize new methods and techniques to enhance information access and delivery. The point here is that the utilization of new methods and technologies for the enhancement of information access and delivery necessarily involves exchange of pecuniary resources. Thus the University of Calabar Library most often appoints and retains a vendor who supplies needed library resources in print and non-print materials to the library. The existence of brokerage transaction here is that the vendors merely act as intermediaries and agents between the library and the real producers and manufacturers of the acquired information resource materials and merely profiting from the transaction on agreed commissions and bonuses.

On the other hand academic libraries with the information and communication technology (ICT) delivery systems can order and make requisition from other information store houses for their needs. This position is supported by Osuala (2001) where he posits that in the Universities, the Internet is one of the most viable tools to obtain important resources for teaching and learning. Therefore, academic libraries with the internet can send out orders to publishers and producers of teaching and learning materials as well as equipment they need for their clients. Again, it must be pointed out here that the availability of brokerage in the above transaction(s) is the fact that the access fees charged by the internet web owners fall within payment as commissions and not necessarily profits. This is so because web owners most often act as agents between libraries and dealers of library materials through the use of their Information and Communication Technology (ICT) super-highway.

Still in the letters and spirit of brokerage transactions, academic libraries subscribe and enter into business retainerships for constant periodic supply of relevant print information materials. Print materials such as law reports, journals, newspapers, and other periodically published materials are always available in academic libraries on time and quantity because agreements are made for the supply of such print materials in the library's collection. This contractual relationship is usually entered into through vendors and other commercial agents with producers who merely benefit in the business by way of payment of commissions. Of course brokers are business agents specializing in engaging third parties in commercial and other agency transactions.

\section{Availability of brokerage on information distribution}

Every academic library must of necessity distribute current information to others and share resources. Thus through the Online Public Access Catalogues (OPAC) academic libraries (with such delivery system) can distribute scarce information on materials in its holding. It is the position of Aina (2003) that where there is full internet access in University libraries the provision and utilization of information services will be possible through cooperation. He summed up by stating that in this direction cooperating libraries will now have access to the catalogues of participating libraries' CD-rom databases, electronic journals, reference resources and other important documents online. Subscription which borders on brokerage to facilitate these transactions, is usually a factor hence the prevalence of information brokerage in 
Academic libraries through payment of subscription and access fees to controlled and regulated websites.

\section{Availability of brokerage on information dissemination}

The advent, adoption and utilization of the information and communication technology (ICT) in the conduct of research and teaching is now a popular phenomenon (Ellis and Oldman, 2005). It is then trite that the use of internet, email and CD-ROMs for access, retrieval and dissemination of information is now very obvious and gaining currency by the day.

Academic libraries are taking advantage of those information delivery systems in the dissemination of valuable information to their yearning clients. Thus brokerage transactions are being undertaken by library practitioners through subscription for access to information databases for the transmission and dissemination of useful information to clients of whatever class. As noted earlier, no client can access any controlled or coded website for information without subscription talkless of retrieving and disseminating such. Of course, there is also copyright restriction which essence is to allow copyright owners recoup and receive pecuniary incentives from published literary and creative works. Thus, publishing houses, be they print or electronic can broker by entering into copyright retainership business agreements with intellectual property owners to publish such creative works to share in the proceeds of such works.

\section{Availability of brokerage on professional services}

Professional bodies usually undertake professional trainings not only as part of their further and continuing education programmes but also to render professional services to needy clients for financial gains. The University of Calabar library as a professional information centre usually conduct in-service and outreach training programmes to requesting clients. Thus in undertaking these programmes it brokers with other professionals by recruiting them as resource persons to render services after which they will be paid commissions from proceeds realized from the programmes. Therefore, the
University of Calabar Library in its bid to discharging its traditional library roles of acquisition processing and storing of information materials and making same accessible to clients, has been undertaking information brokerage transactions thereby sustaining Entrepreneurship Education in Library and Information Science in this part of the country.

The essence of this study therefore has been to assess to what extent academic libraries have been engaging in brokerage transactions and thereby add impetus to same for massive and large scale application.

\section{Methodology}

Services of seven major divisions of the University of Calabar Library were assessed using a descriptive survey research design. A checklist and an interview schedule were served on all divisional heads manning the seven divisional heads of the library to elicit information on the extent of availability of brokerage transactions in the University of Calabar Library. Responses from the seven librarians who constituted the population of study to the questions were with facts and figures. The period under consideration spans 2005 and 2010.

The major divisions consulted were:

- The University Librarian's office

- The Reader Services Division

- The Reference/Bibliographic Services

Division

- The Research Services Division

- Te Resource Development Services Division

- The Processing Services Division

- The Systems/Technical Services Division.

The responses by the Librarians manning the different divisions show that some divisions undertake brokerage services with attendant pecuniary benefits into the library and the University at large while others either undertake brokerage services with attendant pecuniary benefits to the transacting parties or such services would benefit the library directly. A close look at the Table I below will reveal what brokerage service(s) is undertaken by which division and the commission benefiting party. 
Table I

\begin{tabular}{|l|l|l|l|}
\hline $\mathbf{S} / \mathbf{n}$ & \multicolumn{1}{|c|}{ Division } & \multicolumn{1}{|c|}{ Brokerage on services } & $\begin{array}{l}\text { Commission benefiting } \\
\text { parties }\end{array}$ \\
\hline $\mathbf{1}$ & Reader's services & $\begin{array}{l}\text { Information: distribution, } \\
\text { dissemination, and resource showing } \\
\text { etc }\end{array}$ & $\begin{array}{l}\text { Host library and the } \\
\text { transacting party }\end{array}$ \\
\hline 2 & $\begin{array}{l}\text { Reference and } \\
\text { Bibliographic services }\end{array}$ & $\begin{array}{l}\text { Information dissemination, resource } \\
\text { sharing, indexing and abstracting, etc }\end{array}$ & $\begin{array}{l}\text { Host library and the } \\
\text { transacting party }\end{array}$ \\
\hline 3 & Research services & $\begin{array}{l}\text { Information storage, distribution, } \\
\text { dissemination, resource sharing, etc }\end{array}$ & $\begin{array}{l}\text { Host library and the } \\
\text { transacting party }\end{array}$ \\
\hline $\mathbf{4}$ & $\begin{array}{l}\text { Resource } \\
\text { development }\end{array}$ & Information acquisition & $\begin{array}{l}\text { Vendors and other } \\
\text { transacting parties }\end{array}$ \\
\hline $\mathbf{5}$ & Processing & Classification, cataloguing any \\
\hline $\mathbf{6}$ & $\begin{array}{l}\text { Systems/technical } \\
\text { services }\end{array}$ & $\begin{array}{l}\text { Computer and allied services, printing, } \\
\text { binding, royalties, information } \\
\text { distribution, storage dissemination }\end{array}$ & $\begin{array}{l}\text { Host library and and library and } \\
\text { requesting party } \\
\text { transacting parties }\end{array}$ \\
\hline 7 & $\begin{array}{l}\text { The } \\
\text { librarian's office }\end{array}$ & $\begin{array}{l}\text { Issuance of ISBN and ISSN, } \\
\text { professional services }\end{array}$ & $\begin{array}{l}\text { Host library and } \\
\text { transacting parties }\end{array}$ \\
\hline
\end{tabular}

\section{RESULTS AND DISCUSSION}

\section{(i) Brokerage on resource development (acquisition)}

With respect to availability of brokerage on resource acquisition, the study showed that while some other divisions of the Library were earning commission revenue from some of their activities for the library, the Resource Development Division was rather generating such revenue commissions to agents and vendors who transacted businesses with it. Table I below shows that between 2005 and 2010 , the division took delivery of 14,858 textbooks, 14,370 journal issues and 4,400 monographic serials from accredited book vendors representing the publishers of the materials. Apart from about $N 14,400,000.00$ costs paid to vendors in respect of selected newspaper titles and serials, the division paid out about N18,171,433.00 for textbooks and other reference materials.

Table II

\begin{tabular}{|c|c|c|c|}
\hline $\mathbf{S} / \mathbf{N}$ & Type of source & Qty & $\begin{array}{l}\text { Revenue commission } \\
\text { paid out }\end{array}$ \\
\hline 1 & Acquisition of textbooks & 14,858 & $\mathrm{~N} 18,171,433.00$ \\
\hline 2 & $\begin{array}{l}\text { Requisition of journals / reports / serials / } \\
\text { newspapers }\end{array}$ & 19,555 & $\mathrm{~N} 14,400,000.00$ \\
\hline
\end{tabular}

The consolling factor discovered was that the division received information resource materials as gifts from such vendors and agents as donations from the transacting masters. The researchers saw for example, that the law firm of Tony Ukam and Co. donated 200 copies of various legal resource materials while on the other hand had served as a supplying agent of law reports and other legal materials to the University of Calabar library.

Corroborating these findings, Edem (2010) states that the University of Calabar Library received 2,462 volumes of gifts materials 
in book and journal titles, and other information resource materials between 2005 and 2009.

\section{(ii) Brokerage on information distribution and dissemination}

The Reader's Services Division of the University of Calabar undertakes information distribution, dissemination and resource sharing. Data collected from the division show that brokerage transactions on information circulation yielded N76,875.00 from the circulation of 260,304 information materials to clients within the period under review. This revenue was realized from clients' clearance, penalties on overdue information materials and fines for losses and theft from 2005 to 2010, The researchers also noted that if the division had installed or allowed reprographic agents to operate therein, it would have made substantial pecuniary benefits from commissions by such operating agents through photocopying, scanning and other allied services.

\section{(iii) Brokerage on indexing and abstracting}

In the Reference and Bibliographic division, the researchers' collated data which showed that some of the librarians in that division undertook 12 indexing services to 13 potential authors who desired standard published textbooks. A total sum of $\mathrm{N} 120,000.00$ computed as varying commission of between $\mathrm{N} 10,000.00$ to $\mathrm{N} 20,000.00$ per manuscript was realized. It was discovered during oral interview that the division is yet to formulate a standard policy guide to streamline the provision of indexing services in the library. The negative effect of this lack is that
Librarians undertake these services individually than as a corporate body.

(iv) Brokerage on classification and cataloguing

These services are undertaken and rendered by the processing division of the Library. The study discovered that it is the host library that is largely benefiting from the classification and cataloguing services it is undertaking. On enquiry as to patronage from other Libraries, the researchers were informed that some librarians in the division had undertaken classification and cataloguing services for the Akwa Ibom State University of Technology as technical assistance to that institution. However, the study showed that with adequate information on service availability in the division to outsiders, corporate or individual, there will be and upsurge in patronage for its services. Data collected and collated showed that the division classified 751 titles and catalogued 584 volumes within the period under review.

\section{(v) Brokerage on systems/technical services}

The study showed that the System/Technical Services Division undertakes services which include computer services, binding services, printing and publishing services. Data collected and collated showed that patronage from clients came through agents who transacted one technical function or the other with this division on behalf of other individuals or organisations. Table III below shows that a total of 97 technical services were undertaken yielding N179,000.00 within the period understudy. 
Table III

\begin{tabular}{|l|l|l|}
\hline \multicolumn{1}{|c|}{ Type of service } & Volume of work & \multicolumn{1}{c|}{ Commission realized } \\
\hline Binding services & 267 & N80,000.00 \\
\hline Trimming services & 400 & N10,000.00 \\
\hline Training programmes & 11 & N64,000.00 \\
\hline Computer services & 257 & N25,700.00 \\
\hline Total & 925 & N179,700.00 \\
\hline
\end{tabular}

(vi)

\section{Brokerage on publication services (Preview and issuance of ISBN/ISSN services)}

The Library within the period under review facilitated the publication of 97 titles into textbooks and journals from manuscripts submitted by academic and non-academic staff members of the University of Calabar. In this regard, the library submitted the manuscripts of the 97 titles to expert assessors and thereafter issued the International Standard Book Numbers (ISBN) and the International Standard Serial Numbers (ISSN) to the authors on application after payment of the prescribed commission. Table IV below shows that a total of N184,900.00 was generated as commission revenue for the 97 titles published. The breakdown showed that the sum of $N 45,500.00$ was revenue from issuance of the ISBN and ISSN, while the remaining amount was revenue from the peer review of the manuscripts:

Table IV

\begin{tabular}{|c|c|c|c|c|c|}
\hline Year & $\begin{array}{l}\text { Number of titles } \\
\text { received for peer } \\
\text { review }\end{array}$ & $\begin{array}{l}\text { Number of } \\
\text { titles issued } \\
\text { ISBN/ISSN }\end{array}$ & $\begin{array}{l}\text { Commission } \\
\text { revenue for peer } \\
\text { review } \\
\text { (N) }\end{array}$ & $\begin{array}{l}\text { Commission } \\
\text { revenue for } \\
\text { ISBN/ISSN } \\
\text { (N) }\end{array}$ & Total \\
\hline 2005 & 15 & 15 & 20,000 & 7,500 & 27,000 \\
\hline 2006 & 22 & 18 & 27,000 & 9,000 & 36,000 \\
\hline 2007 & 25 & 21 & 31,500 & 10,500 & 41,500 \\
\hline 2008 & 18 & 15 & 22,500 & 7,500 & 30,000 \\
\hline 2009 & 13 & 10 & 15,000 & 5,000 & 20,000 \\
\hline 2010 & 20 & 18 & 24,000 & 6,000 & 30,000 \\
\hline Total & 113 & 97 & 140,000 & 45,500 & 184,900 \\
\hline
\end{tabular}

\section{CONCLUSION AND RECOMMENDATIONS}

It is acceptable expression that Libraries are repositories of knowledge as well as the heart throb of academic institutions. What probably is not common place, is the fact that librarians are potentially active participants in the practice and propagation of aspects of applied economics. This study has shown that academic libraries have consciously and unconsciously been undertaking information brokerage transactions without expressly admitting and listing the term in their service delivery nomenclature.
The result of the omission and partial commission is that the financial benefits which would have facilitated their service delivery have eluded them. With the various and diversified information service delivery systems available in academic Libraries as exemplified in the University of Calabar Library, brokerage transactions could be veritable sources of revenue generation to practicing Libraries and the host Universities at large.

Based on the findings of this study, it is clear that academic libraries are yet to expand 
the economic frontiers inherent in their services delivery and delivery systems. It is therefore necessary that these Libraries engage Librarians with bias in different spheres of human endeavour to take charge of transactions that border on brokerage in information gathering, storage and dissemination as well as professional services. From the foregoing, the following recommendations are deemed necessary for effective application of brokerage transactions in academic libraries in Nigeria.

i) It is imperative that subject-specialist librarianship be adopted wholly to facilitate attainment of financial goals through engagement in specialized service delivery transactions to enhance effective teaching, learning and research in our tertiary institutions. The Industrial Training Fund (ITF) and the National Directorate of Employment (NDE) should be reached out to for training delivery collaborations. Honorarium usually paid out to their facilitators would well serve as budget booster in financial terms.

ii) In the course of the study, the researchers noted that much brokerings took place in the systems/technical allied service division. It is highly recommended that this division be expanded with more ICT gadgets to accommodate all the clients' needs without referrals to outsiders.

iii) For publication necessities, the National Library of Nigeria should be encouraged to allocate a larger range of ISBN and ISSN to the University of Calabar Library to make same readily available to potential authors.

iv) To facilitate the publishing peer review exercise with regard to manuscripts sent in by authors, it is further recommended that an editorial team be instituted to facilitate a better preview liaison publishing activities between the potential authors and the assessors for quick issuance of the copyright numbers. This will remove the lapse that bothers on delay or issuance of either the ISBN or the ISSN to book titles before assessors' recommendation(s).

In all, it is the considered opinion of the researchers that given the glaring commercial tint that academic library services have reflected, also such services should be fully commercialized through the creation of a distinct commercial services division with qualified personnel to man the division. The prevailing situation where brokering services are handled by the same librarians that handle non-brokering services, does not allow for full concentration on the discharge of either of the functions.

\section{REFERENCES}

Aina, L. O., 2003. Strengthening Information Provision in Nigerian University Libraries: The Digital Option in "Compendium of Paper presentation at the 2003 NLA Annual National Conference and AGM" Makurdi, p. 1.

Akintola, B. O., 2006. Fee-charging in Nigerian Public Libraries: A Case study of Oyo State Library Board in Gateway Library Journal 9(2): 33.

Ani, O. E., 2008. Adoption of ICT in Nigerian Polytechnics Libraries. State of the Art in Library Information Practitioner. Journal of the Nigerian Library Association, Cross River Chapter 2(1): 12-24.

Edem, M. B., 2010. Gifts in the University Library Resource Development. Collection Building 29(2): 70-76.

Edoka, B. E., 1991. Prospect of Priced Information Services in Public-Funded Libraries in Nigeria. African Journal of Library, Archives and Information Sciences. 1 (2): 82-92.

Ellis, D. and Oldman, H., 2005. The English Literature Researcher in the Age of the Internet. Journal of Information Science 31(1): 29-36.

Garner, B. A., 2009. Black's Law Dictionary, USA: Thomas Renters Business.

Ifidon, E. I., 2003. and Nwalo, K.I.N. (2003). Marketing Dynamics of Library and Information Services in Nigerian Universities: Contemporary Issues in Educational Management: Book of Honour: 2003. 
Ifidon, E. I., 2005. Fee-based Services, a Means of Making Library Materials Readily Available to Nigerian University (Library) Users. Communicate: Journal of Library and Information Science, 7(1 \& 2): 66 .

International Federation of Library Association. 1987. Journal 13(4)

Johnston, B., 1995. Collier's Encyclopedia vol. 4. New York: P.F. Collier and Sons Ltd.

Nigerian Library Association, Cross River State Chapter, (2005) Communiqué in InfoLibra 2(1): 3.

Nkanu, W. O., 2008. An Assessment of the Extent of Use of Internet in Nigerian University Libraries in Library and Information Practitioner 2(1): 64-72.

Nwamba, A., 2002. The Computerization Process: System Design and Implementation into the Information Age. UK: INASP Publication, Pp 45-65.
Ofre, E. T. and Okwueze, E. U., 2009. Readers' Attitude to Fee-based Services in University of Calabar Library in Gateway Library Journal 12 (2):62-74.

Osuala, S. C., 2001. Internet Services and Internet Connecting: Library Services and Research Potentials in "Teacher Education in the Information Technology Age. Abuja: National Commission for Colleges of Education (NCCE), pp 59-57.

The Encyclopedia America., 2003. vol. 4 Connecticut, USA: Grolier Incorporated.

Unegbu, A. N., 2001. The Information User: Issues and Theme Okigwe: Whyte Publishers Nigeria, p. 29.

Uhegbu, A. N., 2007. The Information user: Issues and Theme Okigwe: Whyte Publishers Nigeria. 